\title{
POTENTIAL PRODUCTION OF THE FIVE PREDOMINANT SMALL PELAGIC FISH SPECIES GROUPS IN THE JAVA SEA
}

\author{
Purwanto', Duto Nugroho ${ }^{2}$, and Suwarso ${ }^{3}$ \\ ${ }^{1}$ The Nature Conservancy - Indonesia Fisheries Conservation Program \& The National \\ Commission for Fisheries Resources Assessment, Jakarta \\ ${ }^{2}$ Research Center for Fisheries Management and Conservation, Jakarta \\ ${ }^{3}$ Research Institute for Marine Fisheries, Jakarta \\ Received June 16-2014; Received in revised form November 12-2014; Accepted November 17-2014 \\ E-Mail: purwanto.pp@gmail.com
}

\begin{abstract}
The Java Sea is one of the important fishing areas for small pelagic fishery in Indonesia. The production of the fishery was dominated by five fish species groups. To support the management of that fishery, an assessment of the stock of the five predominant small pelagic fish species groups was conducted. Based on the result of analysis, the maximum sustainable yield (MSY) of the stock of five predominant small pelagic fish species was about 244.6 thousand tons. Meanwhile, the MSY of the stock of the whole exploitable small pelagic fish species was about 315.5 thousand tons. The optimum fishing effort $\left(E_{\mathrm{MSY}}\right)$ was 1032 units. The total fishing effort was higher than $E_{\mathrm{MSY}}$ and the fish stock was likely over-exploited since 2000. To ensure the optimal fish production of the small pelagic fish stock in the Java Sea, it is necessary to recover fish stock by controlling fishing effort to $E_{\mathrm{MSY}}$. The time which it takes for the fish stock to recover was about two years when fishing effort was reduced from its level in 2009 to $E_{\mathrm{MSY}}$.
\end{abstract}

\section{KEYWORDS: Potential production, optimal fishing effort, small pelagic fishery, the Java Sea}

\section{INTRODUCTION}

Java Sea is one of the important fishing areas for small-scale fishery in Indonesia. The contribution of the Java Sea fisheries to the national economy is significant. This includes supplying fish for domestic consumption and for processing, supporting marketing industries, and providing job opportunities. During 2003 -2012 , about $22 \%$ of marine fisheries production of Indonesia resulted from fishing activities in the Java Sea (DGCF, 2004-2013). The fisheries production of the Java Sea has been contributed mainly by two main fishery resources, namely demersal and smallpelagic fishery resources. During $2003-2012$, the average production of the small pelagic fishery was about $40.7 \%$ of the total fin-fish production from the Java Sea (DGCF, $2004-2013$ ). The majority of the production of the small pelagic fishery from the Java Sea was landed in the northern coast of Java, i.e. about $89 \%$ of the total production during that period.

The small-pelagic resource have been utilised by using various traditional fishing gears long before the Indonesian independence (Dwiponggo, 1987; Butcher, 1995). However, the rapid development of the small pelagic fishery happened after the introduction of purse seine during the early 1970s (Bailey \& Dwiponggo, 1987). The purse seine fleet grew rapidly since early 1990s; sizes of fishing boats and gears have increased to extend fishing operation far away from the base and to be able to catch more fishes (Purwanto, 2003; Cardinale et al., 2009, 2011; Purwanto \& Nugroho,
2011). Consequently, the small-pelagic fishery resource in the Java Sea is reportedly over-exploited (Nurhakim et al., 1995; National Commission on Stock Assessment of Marine Fisheries Resources, 1998; Purwanto, 2003; DMAF, 2007). Considering current development of fishery, the Minister of Marine Affairs and Fisheries stated that the small pelagic fish stock in the Java Sea in the condition of over-exploited (MMAF Decree no 45/Men/ 2011).

The small pelagic fish stock in the Java Sea is a renewable resource having capability to recover when it is harvested, as long as the fishing intensity does not exceed the resource carrying capacity. Increasing fishing intensity to the level higher than the carrying capacity results in the lower production and the lower economic benefits (Purwanto, 2003). An appropriate management strategy is required to sustain small pelagic fish stock and to optimise economic benefit from the utilisation of this fishery resource (Article 6 of the Fisheries Act no. 31 of 2004). To improve management strategy for small pelagic fishery in the Java Sea, it is necessary to assess its fishery resource in order to update information on the potential production of the fishery. The result of the assessment will also be required to develop a policy to manage logistic of fish processing industry in Indonesia.

There were five species groups of the small pelagic fish stock in the Java Sea predominating small pelagic catch and used as raw material in the processing. These species groups include layang (scads - Decapterus spp.), banyar and kembung (mackerels - Rastrelliger 
spp.), tembang (fringscale sardine - Sardinella spp.), bentong (bigeye scads - Selar crumenopthalmus), and siro (spotted sardine - Amblygaster sirm). The total landing of those five species was about $70 \%$ of the total production of small pelagic fishery in the Java Sea during 2003-2012 (DGCF, 2004-2013). Information on the status of stock, fishery and potential production of those five fish species even more important for fisheries management considering the predominance in the small pelagic fishery catches and the importance in the fishery economy of those species. Their stock and fishery in the Java Sea have been assessed, and the result of the assessment is presented in this paper.

\section{MATERIALS AND METHODS}

\section{Model and Method of Analysis}

Analysis was undertaken on the basis of the Schaefer (1957) production model. The model is also discussed in Clark (1976), Hannesson (1978), King (2007), and Haddon (2011). The equations of the model used are as follows:

$x=K-(q \cdot K / r) \cdot E$

$U=(q \cdot K)-\left(q^{2} \cdot K / r\right) \cdot E$

$h=(q \cdot K) \cdot E-\left(q^{2} \cdot K / r\right) \cdot E^{2}$

Where:

$x=$ the stock biomass or population size;

$K=$ the environmentally limited maximum biomass or carrying capacity;

$q$ = catchability coefficient;

$r=$ the natural growth rate of population;

$E=$ fishing effort;

$U=$ catch per unit effort (CPUE);

$h=$ Yield or total catch.

As $U=h / E$, CPUE indicates the actual productivity of fishing effort or fishery. However, based on equations (1) and (2), $U=q . x$, therefore CPUE also indicates the abundance of fish stock. Biological parameters $r$, $K$ and $q$ of the model were estimated using the value of coefficients $a$ and $b$ of the catch per unit effort function as follows:

$U=a-b . E$

For this analysis, the level of fishing effort was estimated as follows:

$E=h / U$
Coefficients $a$ and $b$ of this equation were estimated by ordinary least square method. Then, these coefficients were used to estimate parameters $K, r$ and $q$ by using a method developed by Fox (1975) as follows:

$K=a / q$

$r=q \cdot a / b$

$q=\exp \left[\sum_{t=1}^{n-1} \ln \left|q_{t}\right| /(n-1)\right]$

and

$q_{t}=\ln \left[\left|\left(z_{t} \cdot U_{t}^{1-m}+\frac{1}{b}\right) /\left(z_{t} \cdot U_{t+1}^{1-m}+\frac{1}{b}\right)\right|\right] /\left(z_{t} \cdot m-z_{t}\right)(8)$

Where:

$q$ = the average catchability coefficient over nyears;

$\mathrm{q}_{\mathrm{t}}=$ estimated catchability coefficient in year $t$;

$z_{t}=-a / b-\left(E_{t}+E_{t+1}\right) / 2$;

$U_{t}=$ catch per unit effort in year $t$;

$m=$ constant parameter with a value of 2 for the Schaefer model;

$E_{t}=$ fishing effort in year $t$.

Meanwhile, the maximum sustainable yield (MSY) and fishing effort to produce MSY $\left(E_{\mathrm{MSY}}\right)$ were estimated by using the following equations:

$M S Y=a^{2} /(4 b)=r \cdot K / 4$

$E_{\mathrm{MSY}}=a /(2 b)=r / 2 q$

When the fish stock was over-exploited, fishing activity can be halted or fishing effort can be reduced to recover the fish stock. The time which it takes for the fish stock to recover from $x_{0}$ to $x_{t}$ where fishing effort was reduced to $E_{t}$ can be estimated by using the following equation:

$\Delta t=[1 /(r \cdot S)] \cdot \ln \left\{\left[\left(K-S \cdot x_{0}\right) \cdot x_{t}\right] /\left[\left(K-x_{t}\right) \cdot S \cdot x_{0}\right]\right\}$

Where:

$S=1-(q / r) \cdot E_{t}$

$\Delta t=$ time required to recover;

$x_{0}=$ current population size;

$x_{t}=$ target population size;

$E_{t}=$ fishing effort at $x_{t}$.

Equation (11) was a reformulation of the equation developed by Arreguin-Sanchez (1991). When fishing activity is ceased, $E_{t}=0$ and equation (11) becomes equation (12), which is the same with the one developed by Hannesson (1978), as follows:

$U$ was estimated on the basis 
$\Delta t=(1 / r) \cdot \ln \left\{\left[\left(K-x_{\mathrm{o}}\right) \cdot x_{t}\right] /\left[\left(K-x_{t}\right) \cdot x_{\mathrm{o}}\right]\right\}$

\section{Data}

This study used statistical data and data resulting from fishery monitoring for research purposes during year $1997-2009$. The statistical data were published by DGF during year $1998-2000$ and by DGCF during year $2001-2010$. Meanwhile, the fishery monitoring was undertaken by the Research Institute of Marine Fisheries (RIMF), and covered fishing activities of purse seiners that landed their catches in the northern coast of Java.

The statistical data consisted of data on the production of five predominant species groups of the small pelagic fishes landed in the northern coast of Java and in the western and southern coast of Kalimantan, and data on the number of purse-seine units and the quantity of their catches landed by purseseiners in the northern coast of Java. The number of purse-seine units and the quantity of their catches were used to estimate the catch per purse-seine unit.

The data from RIMF comprised of (1) the size of vessels and their main engine power, and (2) the number of day at sea, the fishing ground, and the catch by species for each purse-seine vessel. The average size and the average main engine of large- sized purse seiners monitored by RIMF were 80 GT and $270 \mathrm{HP}$, respectively.

\section{RESULTS AND DISCUSSION}

\section{Results}

There were two alternative effort units that can be used to measure fishing effort and catch per unit effort of the small pelagic fishery in the Java Sea, namely the number of large-sized purse-seiners monitored by RIMF and the number of purse-seine units reported in the capture fisheries statistic published by DGCF (formerly DGF). Trend of catch per unit effort calculated on the basis of the data collected by RIMF and that calculated on the basis of statistical data published by DGCF were very similar (Figure $1 \mathrm{~A}$ ), with the coefficient of determination of about $89.5 \%$ (Figure $1 \mathrm{~B})$. On the basis of the coefficient of determination $\left(R^{2}\right)$, about $89.5 \%$ of the variation of CPUE calculated on the basis of statistical data can be explained by the variation of the large-sized purse-seiners' CPUE. As the kind of information was available more for the large-sized purse-seiners, therefore, the fishing effort of the small pelagic fishery in the Java Sea was measured by using the number of the large-sized purse-seiners, with vessel size of $80 \mathrm{GT}$ and main engine of $270 \mathrm{HP}$, as it had more information on the fishing fleet.
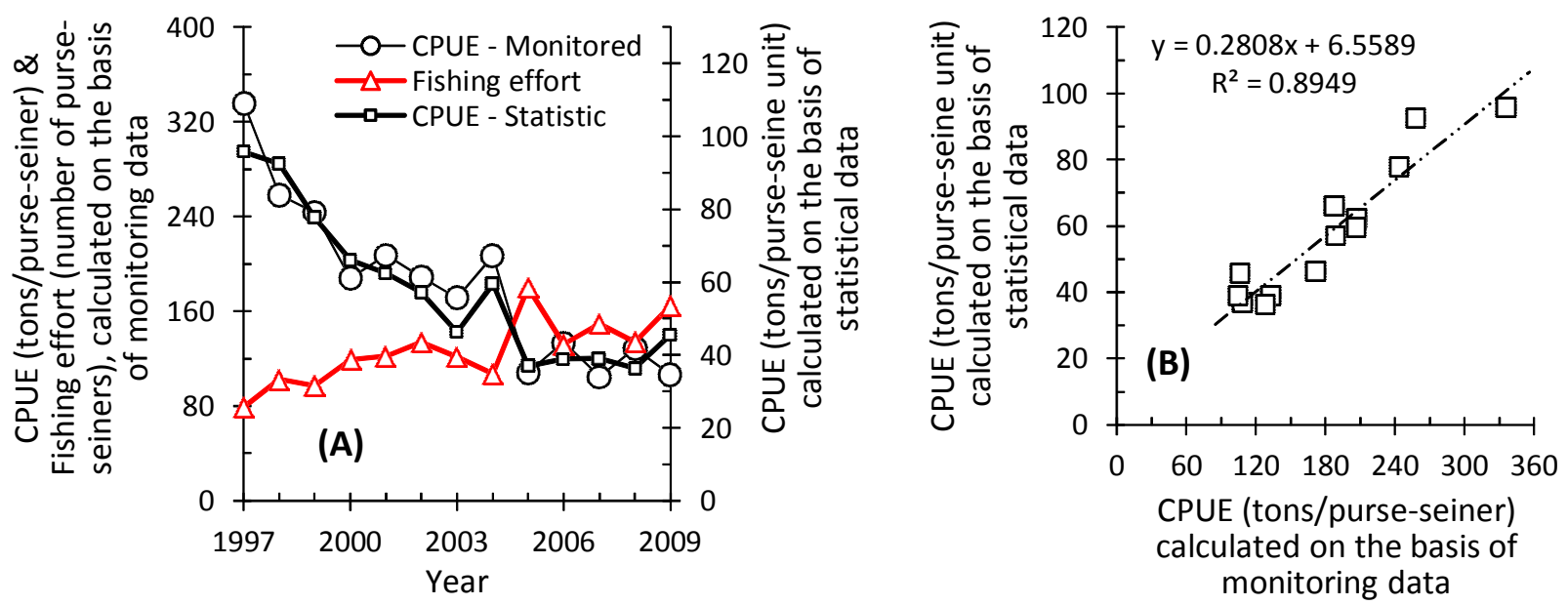

Figure 1. (A) The fluctuation of fishing effort and catch per unit effort (CPUE) of five predominant fish species groups in the small pelagic fishery of the Java Sea, 1997 - 2009, and (B) the relationship between catch per unit effort calculated on the basis of the data collected by RIMF and that calculated on the basis of statistical data published by DGCF. 
During 1997-2009, catch per unit effort tended to decline while fishing effort tended to increase (Figure 1A). The total fishing effort increased from 790 units in 1997 to 1645 units in 2009. On the contrary, the catch per unit effort decline from 336 ton/vessel in 1997 to 106 ton/vessel in 2009. The relationship between the catch per unit effort $(U)$ and the fishing effort $(E)$ in the small pelagic fishery of the Java Sea was significantly represented by the following equation:

$\mathrm{U}=474.2087-0.2299 \mathrm{E}$ $(13.329)^{* * *}(8.181)^{* * \star}$

$\mathrm{R}^{2}=0.8467 ; \quad{ }^{* * *} t$-statistics in the parentheses are significant at $\mathrm{P}<0.001$.

The result of the statistical analysis presentd as Equation (13) shows that the model fits to the data used in this study. The independent variable was significant at $P<0.001$. On the basis of the coefficient of determination $\left(R^{2}\right)$, about $84.7 \%$ of the variation in the dependent variable of the linear equation can be explained by the variation of the independent variable. The biological parameters $K, q$ and $r$, estimated on the basis of the value of the coefficients of Equation (13), were 463311 tons, 0.0010235 and 2.11157, respectively.

The productivity of fishing vessels in the Java Sea small pelagic fishery, as indicated by the catch per unit effort, decreased with increasing fishing effort (Figure 2A). Similarly, the biomass $(x)$ of five predominant species of small pelagic fishes in the Java Sea also decreased with increasing fishing effort (Figure 2B). The relationship between those fish biomass and fishing effort in the Java Sea small pelagic fishery was represented by the following equation:

$x=463310.6-224.576 E$

The catch or yield increased to the maximum level with increasing fishing effort (Figure 2C). After attaining the maximum level, i.e. maximum sustainable yield (MSY), increasing fishing effort resulted in lower catch. The relationship between the quantity of catch and fishing effort in the Java Sea small pelagic fishery was as follows:

$h=474.2087 E-0.2299 E^{2}$
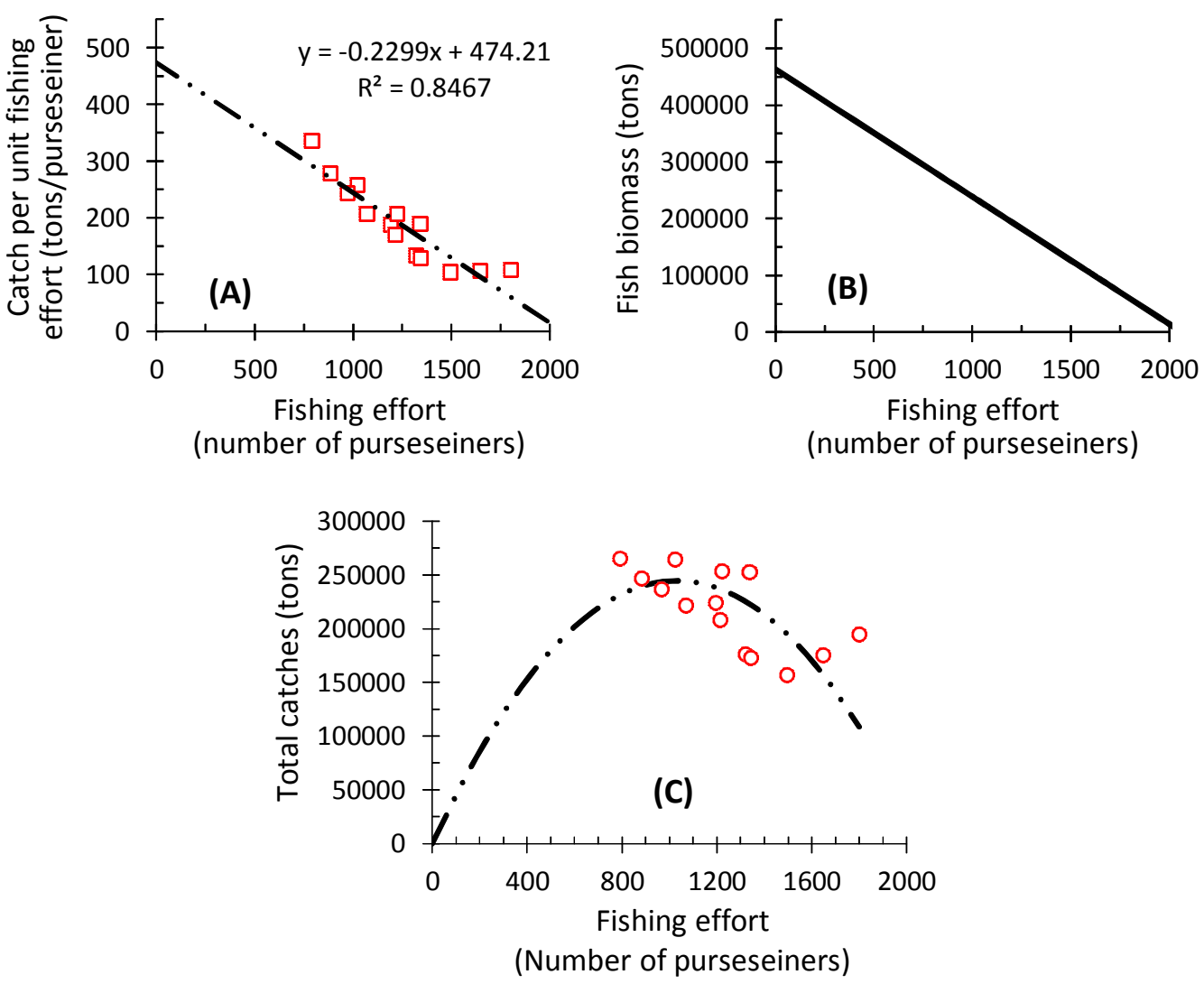

Figure 2. The relationships between fishing effort and: (A) catch per unit effort, (B) biomass and (C) total catch of five predominant fish species groups, in the small pelagic fishery of the Java Sea. 
Table 1. Estimated fishing effort, and estimated biomass, harvest and catch per unit effort of five predominant fish species groups of the small pelagic fishery in the Java Sea in 1997, 2000 and 2009, and their estimated biological optimal levels

\begin{tabular}{llrrrc}
\hline \multirow{2}{*}{ Units } & \multicolumn{3}{c}{ Status of fishery } & \multirow{2}{*}{$\begin{array}{c}\text { Biological } \\
\text { optimal level }\end{array}$} \\
\cline { 3 - 5 } & & Year 1997 & Year 2000 & Year 2009 & option \\
\hline Fishing effort & standard vessels & 790 & 1,191 & 1,645 & 1,032 \\
Biomass & 1000 tons & 285.9 & 195.7 & 93.9 & 231.7 \\
Production of biomass & 1000 tons & 231.2 & 238.7 & 158.0 & 244.6 \\
Harvest & 1000 tons & 231.2 & 238.7 & 158.0 & 244.6 \\
Catch per unit effort & tons/vessel & 292.6 & 200.4 & 96.1 & 237.1 \\
\hline
\end{tabular}

The estimated optimal levels of fishing effort, and biomass, harvest and catch per unit effort of five predominant fish species in the Java Sea small pelagic fishery are presented in Table 1 . The MSY was about 244.6 thousand tons resulting from the operation of 1032 units of large-sized purse-seiners, this was the biologically optimal level of fishing effort $\left(E_{\text {MSY }}\right)$. Meanwhile, optimal catch per unit effort $\left(U_{\text {MSY }}\right)$ was about 237 tons per vessel.

The contribution of the five predominant fish species groups to the production of the small pelagic fishery from the Java Sea was about $78 \%$ of the total production of this fishery in 1998. The fishing effort in 1998 was about 1022 unit, which was $9 \%$ lower than the $E_{\mathrm{MSY}}$. Meanwhile, the average annual fishing effort during $1997-2001$ was about 1039 unit, which was $7 \%$ higher than the $E_{\mathrm{MSY}}$. The average contribution of the five predominant fish species groups to the production of the small pelagic fishery from the Java Sea was about $78 \%$ of the total production of this fishery during 1997 - 2001. Based on the contribution of those five predominant fish species to the production of the small pelagic fishery from the Java Sea at about

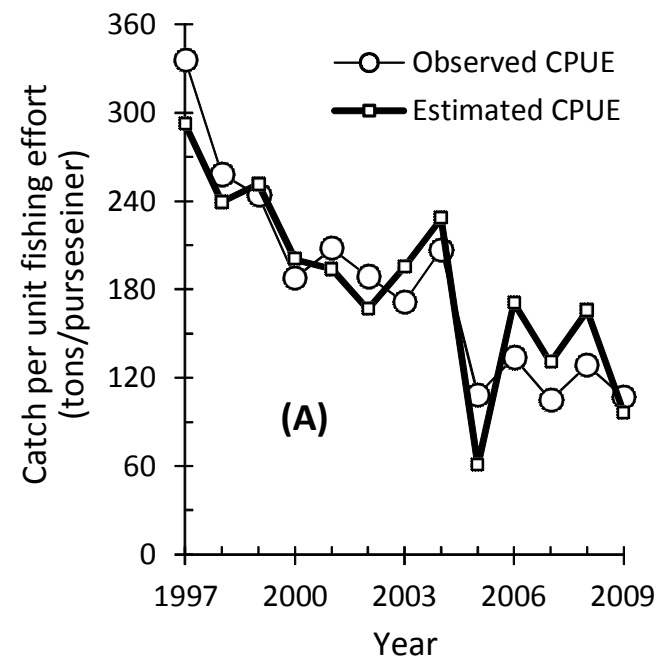

the MSY level, i.e. $78 \%$, the estimated MSY from utilizing the stock of the whole exploitable small pelagic fish species groups in the Java Sea was about 315.5 thousand tons.

Comparing the fishing effort level and the fish stock abundance, as indicated by the catch per unit effort, with their estimated optimal levels, the development of small pelagic fishery in the Java Sea during the period of assessment $(1997-2009)$ can be divided into two segments of fishery development. The first segment, during $1997-1999$, small pelagic fishery was utilizing the stock of five predominant species groups of small pelagic fishes in the Java Sea at the level of effort lower than the $E_{\mathrm{MSY}}$, and the abundance of that fish stock was at a safe level, as indicated by its CPUE that was higher than $U_{\text {MSY }}$ (Figures $1 \mathrm{~A}$ \& 3A; Table 1; Appendix 1). The second segment, since 2000 , the small pelagic fishery was over-exploiting the stock of five predominant species groups of small pelagic, and the fish stock was in the over-exploited condition, as indicated by its CPUE that was lower than $U_{\text {MSY }}$. Those conditions can be shown from plotting the relative fishing effort, i.e. fishing effort at

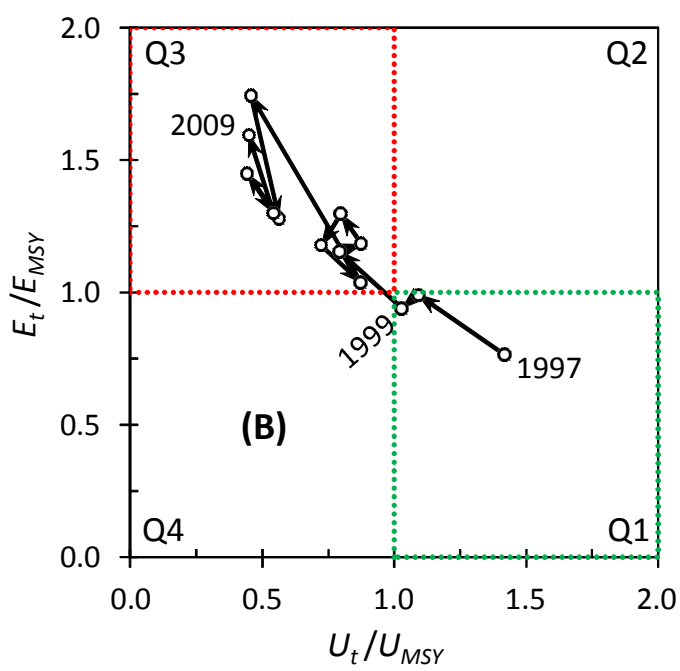

Figure 3. (A) Development of catch per unit effort (CPUE), and (B) development of the relative fishing effort and relative abundance of the stock of five predominant fish species groups, as indicated by relative CPUE, of the small pelagic fishery in the Java Sea, 1997-2009. 
each year divided by optimal fishing effort level, and relative abundance of stock, indicated by estimated stock abundance index at each year divided by optimal stock abundance index (Figure 3B). The first segment was in quadrant-1 (Q1) where $E / E_{\mathrm{MSY}}<1$ and $U / U_{\mathrm{MSY}}$ $>1$, while the second segment was in quadrant-3 (Q3) where $E / E_{\mathrm{MSY}}>1$ and $U / U_{\mathrm{MSY}}<1$.

The fish stock can be recovered from the overexploited level in 2009, i.e. 93.9 thousand tones, to the optimal stock level, i.e. 231.7 thousand tones, by halting fishing activity or by reducing fishing effort from its level in 2009, i.e. 1645 units, to $E_{\mathrm{MSY}}$. The time which it takes for the fish stock to recover was about 8 months when fishing activity was halted. On the other hand, it would take about 25 months for the fish stock to recover when fishing effort was reduced from its level in 2009 to $E_{\mathrm{MSY}}$.

\section{Discussion}

This analysis shows that the trend of CPUE estimated on the basis of statistical data published by the DGCF was very similar to the trend of catch per purse-seiner calculated on the basis of data resulting from monitoring fishing activity of purse seiners in the Java Sea undertaken by RIMF (Figure 1). Those two sets of data were highly correlated, indicating that the assessment of small pelagic fishery in the Java Sea can also be undertaken by using CPUE calculated on the basis of statistical data published by DGCF as an alternative to that resulting from research activity.

Furthermore, the significant relationship and the high correlation between the catch per purse-seiner and fishing effort calculated on the basis of the statistical data on small pelagic fishery production (Equation 13), shows the possibility to use the statistical data collected and published by DGCF in the assessment of fishery and stock of small pelagic fishes in the Java Sea (Figure 2; Table 2). The existence of unreported fishing may result in a serious problem in the validity and the reliability of the capture fisheries statistical data that could result in poor quality of fish stock assessment. That problem happened, for example, in the Arafura Sea fishery (Purwanto, 2014 a,b). To ensure the quality of the assessment, proper estimation of unreported fishing activity should be undertaken and taken into account during data collection and processing in order to have valid and reliable statistical data. However, there was no information on the magnitude of unreported fishing targeting small pelagic fishes in the Java Sea so far.
The result of this study that covered years 1997 2009 indicated that the small pelagic fishery was overexploiting the stock of five predominant species groups of small pelagic fishes, and the fish stock was in the over-exploited condition since 2000 (Figure 3). Consequently, the production of five predominant species groups of small pelagic fishes and the productivity of purse-seiners were sub-optimal (Figure $2 A, C)$. There was no latest assessment of the economic consequences of the fishery over-exploiting the small pelagic fish stock in the Java Sea. However, previous study shows that the economic benefits of the fishery was also sub-optimal when fish stock was over-exploited (Kuntjoro, 1986; Purwanto, 2003). The same case in the small pelagic fishery of Indonesia was reported from bio-economic study in the lemuru fishery of the Bali Strait (Purwanto, 2008, 2011). To ensure the optimal fish production and the optimal economic benefits from small pelagic fishery in the Java Sea, it is necessary to control fishing effort to the optimal level.

The fish stock can be recovered from the overexploited condition by either halting fishing activity or by reducing fishing effort. The time which it takes for the fish stock to recover when fishing activity was halted would be shorter than that when fishing effort was reduced to $E_{\mathrm{MSY}}$. However, the social and economic consequences of those two alternative of effort control to recover the over-exploited stock would be different. As there was no study on the social and economic consequences of those two alternatives of effort control, it is necessary to also conduct social and economic studies to add other dimension in the evaluation of effort control policy alternatives.

\section{CONCLUSIONS AND RECOMENDATIONS Conclusions}

1. The maximum sustainable yield (MSY) from utilizing the stock of five predominant small fish species groups in the Java Sea was about 244.6 thousand tons. Meanwhile, the MSY from utilizing the stock of the whole exploitable small pelagic fish species in the Java Sea was about 315.5 thousand tons;

2. The optimum level of fishing effort $\left(E_{\mathrm{MSY}}\right)$ was 1032 units;

3. The small pelagic fishery was over-exploiting the stock of five predominant species groups of small pelagic fishes, and the fish stock was in the overexploited condition since 2000 ;

4. The time which it takes for the fish stock to recover when fishing activity was halted would be shorter than that when fishing effort was reduced to $E_{\mathrm{MSY}}$. 


\section{Recommendations}

1. To ensure the optimal fish production of small pelagic fishery in the Java Sea, it is necessary to recover fish stock by controlling fishing effort to and maintaining fishing effort at the optimal level;

2. The social and economic consequences of various alternatives of effort control to recover the overexploited stock would be different. Therefore, it is necessary to also conduct social and economic studies to add other dimension in the evaluation of effort control policy alternatives;

3. To ensure the quality of small pelagic fishery assessment in the Java Sea, proper estimation of unreported fishing activity in that fishing ground should be undertaken and taken into account during data collection and processing in order to have valid and reliable statistical data.

\section{ACKNOWLEDGEMENT}

This study was benefited from the research project activity on the monitoring of small pelagic fishery monitoring in the northern coast of Java undertaken by Research Institute for Marine Fisheries during 1997-2009.

\section{REFERENCES}

Arreguin-Sanchez, F. 1991. Time recovery for exploited fish populations based on surplus yield models. Fishbyte, Dec. 1991: $39-41$.

Bailey, C. \& A. Dwiponggo. 1987. Indonesian marine fisheries: Structure and change. p. 64-88. In C. Bailey, A. Dwiponggo and F. Marahudin (eds.) Indonesian marine capture fisheries. ICLARM Studies and Review 10.

Butcher, J.G. 1995. Extending the frontier: the marine fisheries of Southeast Asia since 1850. p. 19-28. In J. Roch, S. Nurhakim, J. Widodo and A. Poernomo (eds.) Proceedings of Socioeconomics, Innovation and Management of the Java Sea Pelagic Fisheries (SOSEKIMA), 4-7 December 1995. Java Sea Pelagic Fishery Assessment Project, Jakarta.

Cardinale, M., D. Nugroho \& L. Hernroth. 2009. Reconstructing historical trends of small pelagic fish in the Java Sea using standardized commercial trip based catch per unit of effort. Fisheries Research 99: 151-158.
Cardinale, M., D. Nugroho \& P. Jonson. 2011. Serial depletion of fishing grounds in an unregulated, open access fishery. Fisheries Research 108: 106-111.

Clark, C.W. 1976. Mathematical Bioeconomics: the optimal management of renewable resources. John Wiley and Sons, New York.

Department of Marine Affairs and Fisheries (Departemen Kelautan dan Perikanan). 2007. Buku Statistik Kelautan dan Perikanan. DKP, Jakarta.

Directorate General of Capture Fisheries. 2001-2013. Statistik Perikanan Tangkap Indonesia. DGCF, Jakarta.

Directorate General of Fisheries. 1998-2000. Statistik Perikanan Indonesia. DGF, Jakarta.

Dwiponggo, A.1987. Indonesian marine fisheries resources. p. 10-63. In C. Bailey, A. Dwiponggo and F. Marahudin (eds.) Indonesian marine capture fisheries. ICLARM Studies and Review 10. 196p.

Fisheries Act no. 31 of 2004 on Fisheries.

Fox, W.W. 1975. Fitting the generalized stock production model by least-squares and equilibrium approximation. Fishery Bulletin 73(1): 23-37.

Haddon, M. 2011. Modelling and Quantitative Methods in Fisheries. 2nd edn. Chapman \& Hall/CRC. Boca Raton. 449p.

Hannesson, R. 1978. Economics of Fisheries: An introduction. Universitetforlaget. Bergen. 156p.

King, M. 2007. Fisheries Biology, Assessment and Management. Blackwell Publishing. Oxford. 382p.

Kuntjoro, K. D. 1986. Bionomic assessment of the marine fisheries in the northern coast of Central Java. MS Thesis. The Faculty of Resource Economics and Agribusiness, Universiti Pertanian Malaysia. 141p.

Minister of Marine Affairs and Fisheries (MMAF) Decree (Keputusan Menteri Kelautan dan Perikanan) nomor 45/Men/2011 tentang Estimasi Potensi Sumberdaya lkan di Wilayah Pengelolaan Perikanan Negara Republik Indonesia.

National Commission on Stock Assessment of Marine Fisheries Resources. 1998. Potensi dan 
Penyebaran Sumberdaya Ikan Laut di Perairan Indonesia. Directorate General of Fisheries, Jakarta. $42 \mathrm{p}$.

Nurhakim, S., B. Sadhotomo \& M. Potier. 1995. Composite model on small pelagic resources. p. 145-153. In M. Potier and S. Nurhakim (eds.) Proceedings of the Seminar on Biology, Dynamic and Exploitation of Javanese Purse-seiners Fisheries (BIODYNEX). Agency for Agricultural Research and Development, Indonesia, ORSTOM and European Union.

Purwanto. 2003. Status and management of the Java Sea fisheries. 793-832. In G. Silvestre, L. Garces, I. Stobutzki, M. Ahmed, R. A. Valmonte-Santos, C. Luna, L. Lachica-Aliño, P. Munro, V. Christensen, \& D. Pauly (eds.) Assessment, Management, and Future Directions for Coastal Fisheries in Asian Countries. World Fish Center Conference Proceeding 67: 1120p.

Purwanto. 2008. Resource rent generated in the Bali strait sardine fishery in a fluctuating environment. Final Draft. Prepared for the World Bank PROFISH Program. Washington. D.C. 33p.
Purwanto. 2011. Bio-economic optimal levels of the Bali strait sardine fishery operating in a fluctuating environment. Ind. Fish. Res. J., 17(1): 1-12.

Purwanto. 2014a. Estimasi produksi udang yang tidak dilaporkan dari kegiatan penangkapan di Laut Arafura.

Purwanto. 2014b. Biomasa, produktivitas kapal penangkap dan potensi produksi ikan demersal di Laut Arafura.

Purwanto \& D. Nugroho. 2011. Daya tangkap kapal pukat cincin dan upaya penangkapan pada perikanan pelagis kecil di Laut Jawa. J. Lit. Perikan. Ind., 17(1): 23-30.

Schaefer, M. B. 1957. Some considerations of population dynamics and economics in relation to the management of the commercial marine fisheries. Journal of Fisheries Research Board of Canada 14: 669-681. 
Appendix 1. Total catches and catch per unit fishing effort of five predominant small pelagic fish species 1 , and fishing effort of the small pelagic fishery in the Java Sea, 1997-2012

\begin{tabular}{cccc}
\hline Year & $\begin{array}{c}\text { Total catches } \\
\text { (tons) }\end{array}$ & $\begin{array}{c}\text { Catch per unit fishing } \\
\text { effort (tons/vessel/year) }\end{array}$ & $\begin{array}{c}\text { Fishing effort } \\
\text { (the number of } \mathbf{8 0}^{\mathbf{b}} \mathbf{G T} \\
\text { purse-seiners) }\end{array}$ \\
\hline 1997 & $h$ & $U$ & $E^{\underline{\mathbf{2}}}$ \\
1998 & 265367 & 336 & 790 \\
1999 & 264163 & 258 & 1022 \\
2000 & 236428 & 244 & 969 \\
2001 & 224028 & 188 & 1191 \\
2002 & 253292 & 208 & 1220 \\
2003 & 252984 & 189 & 1338 \\
2004 & 208072 & 171 & 1214 \\
2005 & 221500 & 207 & 1070 \\
2006 & 195041 & 108 & 1800 \\
2007 & 176400 & 134 & 1319 \\
2008 & 156816 & 105 & 1495 \\
2009 & 172566 & 129 & 1342 \\
\hline
\end{tabular}

Remarks:

1. Five predominant fish species caught by small pelagic fishery comprised of layang (scads - Decapterus spp.), banyar and kembung (mackerels - Rastrelligerspp.), tembang (fringscale sardine - Sardinella spp.), bentong (bigeye scads - Selar crumenopthalmus), and siro (spotted sardine - Amblygaster sirm);

2. $E=h / U$;

3. Sources of data: a. DGF (1998-2000) and DGCF (2001-2010); b. RIMF. 